\title{
Distribution, threats and conservation of the White-collared Kite (Leptodon forbesi, Accipitridae), the most threatened raptor in the Neotropics
}

\author{
Glauco Alves Pereira, ${ }^{1,5}$; Helder Farias Pereira de Araújo ${ }^{2}$; Severino Mendes de Azevedo Júnior ${ }^{1,6}$; \\ Cíntia Camila Silva Angelieri ${ }^{3}$ \& Luís Fábio Silveira ${ }^{4}$
}

\footnotetext{
1 Universidade Federal Rural de Pernambuco (UFRPE), Departamento de Biologia (DB), Laboratório de Ornitologia, Programa de Pós-Graduação em Etnobiologia e Conservação da Natureza (PPGEtno). Recife, PE, Brasil.

2 Universidade Federal da Paraíba (UFPB), Centro de Ciências Biológicas, Departamento de Ciências Biológicas (DCB). Areia, PB, Brasil. ORCID: http://orcid.org/0000-0001-6237-6490.E-mail: helder@cca.ufpb.br

3 Universidade de São Paulo (USP), Escola de Engenharia de São Carlos (EESC), Programa de Pós Graduação em Ciências da Engenharia Ambiental (PPG-SEA). São Carlos, SP, Brasil. ORCID: http://orcid.org/0000-0003-2247-1244. E-mail: biocicamila@gmail.com

${ }^{4}$ Universidade de São Paulo (USP), Museu de Zoologia (MZUSP). São Paulo, SP, Brasil. ORCID: http://orcid.org/0000-0003-2576-7657.E-mail: Ifs@usp.br

${ }^{5}$ ORCID: http://orcid.org/0000-0003-2435-2062. E-mail: glaucoapereira@hotmail.com (corresponding author)

${ }^{6}$ ORCID: http://orcid.org/0000-0002-1274-7481.E-mail: smaj@db.ufrpe.br
}

\begin{abstract}
The White-collared Kite (Leptodon forbesi) is an endemic and threatened raptor of the Brazilian Atlantic Forest. Here we present the known records of the species, describe the vegetation types where it was found and show Ecological Niche Models generated using Maxent algorithm. Most of the presence data were recorded in open ombrophilous forest and seasonal semideciduous forest in the states of Alagoas and Pernambuco. Maxent model had a good performance (AUC $=0.982 \pm 0.004$ SD), showing higher suitability for the species from Paraíba to Alagoas states. Maxent average model revealed a distribution range of $20,344 \mathrm{~km}^{2}$ and an area of occupancy of $1,636.89 \mathrm{~km}^{2}$. The most suitable areas for the species are those near watercourses and streams. We suggest the creation of protected areas, including private ones, and possible restoration actions to connect the most suitable forest fragments, along with the captive breeding, as the most appropriate strategies for the conservation of the White-collared Kite.
\end{abstract}

Key-Words. Raptors; Atlantic Forest; Brazil; Biogeography; Niche modeling.

\section{INTRODUCTION}

The White-collared Kite Leptodon forbesi (Swann, 1922; Fig. 1) is a diurnal raptor endemic to the Atlantic Forest of northeastern Brazil. It occurs in the states of Rio Grande do Norte, Paraíba, Pernambuco, Alagoas, in the Pernambuco Center of Endemism, with a handful of records in Sergipe and northern Bahia (Dénes et al., 2011; Pereira et al., 2014; IUCN, 2016; Leite et al., 2017; WikiAves, 2018). Until the beginning of the first decade of the $21^{\text {th }}$ century almost nothing was known about $L$. forbesi and several authors, due the lack of specimens or even sight records, doubted the validity of the species. However, in the past ten years the literature on L. forbesi's biology, taxonomy and ecology has significantly grown, and its specific status is no longer a question (Dénes et al., 2011; Seipke et al., 2011).
Leptodon forbesi is considered endangered both by international (IUCN, 2016) and national red lists (Brasil, 2014). Although L. forbesi was found in quite disturbed habitats, massive deforestation in the Atlantic Forest of northeastern Brazil and consequent habitat loss of habitat are the main threats for this species (IUCN, 2018). The extinction of many elements in this region is occurring now due the existing time lag between deforestation and extinction of endemic and threatened birds (Brooks \& Balmford, 1996; Brooks et al., 1999), as noticed for the birds (Pereira et al., 2014). Ultimately, L. forbesi has been recorded sporadically even in urban forests of state capitals such as João Pessoa and Maceió, in NE Brazil (Pereira et al., 2014), but no evidence of breeding activities was observed in these places. 
We compiled 41 records of $L$. forbesi (Table 1), visiting all areas except those in Bahia and Rio Grande do Norte for validation (see below). To diminish sampling bias (see Brown, 2014), sampling data were rarefied by spatially filtering locality data by $1 \mathrm{~km}$ radius input Euclidian distance using SDMtoolbox v1.1b (Brown, 2014). This technique reduced occurrence data to a single point within $\sim 7 \mathrm{~km}^{2}$, based on the species' home range, resulting in 31 independent records.

Twenty-one environmental variables (19 climatic and 2 topographic) were tested as potential predictors for ENMs. The climatic variables were obtained from the Worldclim bioclimatic database (Hijmans et al., 2005) and the topographic variables (elevation and declivity) were derived from the Shuttle Radar Topography Mition - SRTM (Jarvis et al., 2008). All the environmental variables are available for Brazil in ASCII grid format, World Geodetic System 1984 (WGS-84), and 30 arc-seconds resolution ( $1 \mathrm{~km}$ ) (Amaral et al., 2013).

To avoid overparameterization with redundant variables, we removed the strongly correlated ones (Dormann et al., 2007). Therefore, variables with high correlation $(r>0.7)$ were eliminated, and a subset of 10 uncorrelated environmental variables was selected: mean diurnal range - bio 2, temperature seasonality bio 4 (mean of monthly (max temp - min temp)), mean temperature of wettest quarter - bio 8, precipitation of driest month - bio 14, precipitation seasonality - bio 15 (coefficient of variation), precipitation of wettest quarter - bio 16, precipitation of warmest quarter - bio 18, precipitation of coldest quarter - bio 19, elevation, and declivity. For details on climatic variables see Hijmans et al. (2005).

The R Package 'dismo' (version 1.1-4) was used to apply the maximum entropy algorithm (Maxent - version 3.3.3k - Hijmans et al., 2017). This algorithm uses environmental variables that are relevant to the species and presence-only data to calculate the probability of presence, making good predictions or inferences even with incomplete available data (Phillips et al., 2006). Following Phillips et al. (2006), the model was generated by 10 bootstrapping randomly the presence records into training ( $75 \%$ of the records) and test ( $25 \%$ of the records).

The Receiver Operating Characteristics (ROC) was analyzed to evaluate the model performance, comparing to random prediction (Baldwin, 2009). The significance of the ROC plot is quantified using the Area Under the Curve (henceforth AUC) (Fielding \& Bell, 1997). AUC provides a single measure of the model's performance, regardless of any threshold rule (Phillips et al., 2006). Models with AUC $\geq 0.5$ are able to predict the species presence better than by chance, but only models with AUC $\geq 0.75$ are considered potentially useful for species distribution modeling (Elith, 2002).

A $p$-value test was used to evaluate the significance of the average model, where $p \leq 0.05$ was considered better than a random prediction (Pearson et al., 2007). The maximum training sensitivity plus specificity logistic threshold was applied for binary classification in ArcGis 10.2. If the probability value was equal or greater than this 
Table 1. Localities, geographical coordinates (WGS 84), vegetation types and the sources records where Leptodon forbesi was recorded from 1987 to 2019.

\begin{tabular}{|c|c|c|c|c|c|}
\hline Locality & Municipality/State & Longitude & Latitude & VegetationType & Source \\
\hline REBI0 Guaribas & Mamanguape, Rio Tinto/PB & -6.716667 & -35.183333 & SSF/ETZ & Glauco Pereira (pers. obs., 2013) \\
\hline RPPN Fazenda Pacatuba & Sapé/PB & -7.037222 & -35.159444 & SSF & Frederico Sonntag (pers. com., 2015) \\
\hline RPPN Engenho Gargaú & Santa Rita/PB & -7.020833 & -34.958889 & SSF & Pereira et al. (2014) \\
\hline APP Mata do Buraquinho & João Pessoa/PB & -7.148611 & -34.861667 & ETZ & Pereira et al. (2014) \\
\hline Fazenda Cidade Viva & Conde/PB & -7.222500 & -34.921389 & $\mathrm{ETZ}$ & Pereira et al. (2014) \\
\hline PE Mata do Pau Ferro & Areia/PB & -6.968333 & -35.745833 & $00 \mathrm{~F}$ & Caio Brito and Nailson Junior (pers. com., 2015) \\
\hline Mata do Estado & São Vicente Férrer/PE & -7.619444 & -35.511111 & ETZ & Pereira et al. (2014) \\
\hline Engenho Água Azul & Timbaúba/PE & -7.609167 & -35.405000 & SSF & Collar et al. (2000); Pereira et al. (2014) \\
\hline Mata de Aldeia & Abreu e Lima, Camaragibe, Pau D'alho/PE & -7.904444 & -35.056389 & $00 \mathrm{~F}$ & Pereira et al. (2014) \\
\hline ESEC Caetés & Paulista/PE & -7.927500 & -34.931111 & $00 \mathrm{~F}$ & Pereira et al. (2014) \\
\hline PE de Dois Irmãos & Recife/PE & -8.000833 & -34.945278 & $00 \mathrm{~F}$ & Glauco Pereira (pers. obs., 2015) \\
\hline Mata do Benedito/Engenho Jussará & Gravatá/PE & -8.293889 & -35.589167 & SSF & Pereira et al. (2014) \\
\hline Sítio do Contente & Gravatá/PE & -8.266667 & -35.543611 & SSF & Pereira et al. (2014) \\
\hline Engenho Brejão & Bonito/PE & -8.548611 & -35.729722 & SSF/ETZ & Pereira et al. (2014) \\
\hline Mata da Cutia/Leão & Sirinhaém/PE & -8.541944 & -35.170556 & DOF & Seipke et al. (2011) \\
\hline Mata das Cobras & Sirinhaém/PE & -8.553611 & -35.147222 & DOF & Seipke et al. (2011) \\
\hline Mata do Dêra/Tauá & Sirinhaém/PE & -8.571389 & -35.170833 & $\mathrm{DOF}$ & Seipke et al. (2011) \\
\hline Mata de Xanguá/Usina Trapiche & Rio Formoso/PE & -8.629444 & -35.186667 & DOF & Pereira et al. (2014) \\
\hline Engenho Cachoeira Linda & Barreiros/PE & -8.821111 & -35.315550 & DOF & Pereira et al. (2006), Seipke et al. (2011) \\
\hline Engenho Roncadorzinho & Barreiros/PE & -8.811667 & -35.296111 & DOF & Glauco Pereira (pers. obs., 2009) \\
\hline RPPN Eco Fazenda Morim/Mata do Cristovão & São José da Coroa Grande/PE & -8.878056 & -35.218889 & DOF & Pereira et al. (2014) \\
\hline RPPN Frei Caneca/RPPN Pedra D'Anta & Jaqueira/Lagoa dos Gatos/PE & -8.716944 & -35.843611 & SSF/OOF & Stephen Jones (pers. com., 2013) \\
\hline Engenho Gigante/Usina Una Álcool & Maraial/PE & -8.794167 & -35.773889 & $00 \mathrm{~F}$ & Glauco Pereira (pers. obs., 2009) \\
\hline Mata da Cunha/Fazenda Soberana & São Benedito do Sul/PE & -8.852500 & -35.905000 & $00 \mathrm{~F}$ & Glauco Pereira (pers. obs., 2009) \\
\hline Engenho Coimbra/Usina Serra Grande & Ibateguara/AL & -9.003889 & -35.845556 & $00 \mathrm{~F}$ & Seipke et al. (2011) \\
\hline Mata do Espinho/Usina Serra Grande & São José da Laje/AL & -8.950556 & -36.019444 & SSF & Seipke et al. (2011) \\
\hline Mata da Cachoeira/Usina Serra Grande & São José da Laje/AL & -8.941944 & -36.058889 & SSF & Seipke et al. (2011) \\
\hline Mata da Capiana & São José da Laje/AL & -8.941111 & -36.001389 & SSF & Seipke et al. (2011) \\
\hline Mata do Pinto/Usina Serra Grande & São José da Laje/AL & -8.980000 & -36.105556 & SSF & Seipke et al. (2011) \\
\hline RPPN Boa Sorte & Murici/AL & -9.191944 & -35.932778 & $00 \mathrm{~F}$ & Seipke et al. (2011) \\
\hline ESEC Murici & Murici, Messias/AL & -9.205556 & -35.870556 & $00 \mathrm{~F}$ & Teixeira et al. (1987); Seipke et al. (2011) \\
\hline Usina Santo Antônio & Passo de Camaragibe/AL & -9.221667 & -35.526944 & $00 \mathrm{~F}$ & Glauco Pereira (pers. obs., 2013) \\
\hline Fazenda Cachoeira & Pindoba/AL & -9.477778 & -36.347778 & $00 \mathrm{~F}$ & Pereira et al. (2014) \\
\hline Mata do Cedro & Rio Largo/AL & -9.522500 & -35.913056 & $00 \mathrm{~F}$ & Glauco Pereira (pers. obs., 2013) \\
\hline Parque Municipal de Maceió & Maceió/AL & -9.612500 & -35.762500 & $00 \mathrm{~F}$ & Pereira et al. (2014) \\
\hline Fazenda Varrela & São Miguel dos Campos/AL & -9.710000 & -36.007500 & $00 \mathrm{~F}$ & Pereira et al. (2006); Seipke et al. (2011) \\
\hline Lagoa do Roteiro & Roteiro/AL & -9.822222 & -35.993611 & $00 \mathrm{~F}$ & Seipke et al. (2011) \\
\hline RPPN Madeiras & Junqueiro/AL & -9.865556 & -36.333056 & SSF & Pereira et al. (2014) \\
\hline Mata do Capiatã/Usina Coruripe & Coruripe/AL & -10.008056 & -36.282500 & SSF & Pereira et al. (2014) \\
\hline Mata do Crasto/APA do Litoral Sul & Santa Luzia do Itanhy/SE & -11.367222 & -37.417222 & SSF & Pereira et al. (2014) \\
\hline
\end{tabular}

States: $\mathrm{AL}=$ = Alagoas, $\mathrm{PB}=$ Paraíba, PE = Pernambuco, and SE = Sergipe. Protected areas: $\mathrm{APP}=$ Permanent Protection Area; ESEC = Ecological Station; PE = State Park; REBI0 = Biological Reserve; $A P A=$ Environmental Protection Area, and RPPN = Private Reserve of Natural Heritage. Vegetation types: $00 \mathrm{~F}=$ open ombrophilous forest; $\mathrm{DOF}=$ dense ombrophilous forest; $\mathrm{ETZ}=\mathrm{ecological}$ tension zone, and SSF = seasonal semideciduous forest.

threshold value, it was classified as suitable for L. forbesi, otherwise unsuitable (Trisurat \& Duengkae, 2011). These approaches (sensitivity-specificity) are widely used and have great accuracy (Liu et al., 2005). Finally, it was performed a heuristic estimate of the variables relative contribution to the model.

Following IUCN (2001) we estimated the potential suitable area by measuring the extent of occurrence, and calculating the area of occupancy. In the case of $L$. forbesi only fragments larger than $1 \mathrm{~km}^{2}$ were considered (the smallest area where the species was recorded). We also excluded the records from Sergipe and Bahia from the analysis, and more studies must be conducted at these sites to confirm the existence of populations. These re- cords may refer to vagrant individuals, as correctly stated by Leite et al. (2017).

Finally, ArcGIS 10.2 was used to overlap the species' habitat suitability map with the maps of Atlantic Forest fragments and Brazilian Protected Areas (SNUC, 2004; Fundação SOS Mata Atlântica, 2015).

\section{RESULTS}

Current records of $L$. forbesi (82.5\%) are concentrated in the Brazilian states of Pernambuco and Alagoas, with isolated records in Sergipe, Paraíba, Rio Grande do Norte, and Bahia. Observations of the species in Open 
Table 2. Distribution of the records of Leptodon forbesi in different vegetation types.

\begin{tabular}{ccc}
\hline Vegetation type & Number of records & $\%$ \\
\hline OOF & 15 & 37.5 \\
DOF & 7 & 17.5 \\
SSF & 12 & 30 \\
ETZ & 3 & 7.5 \\
SSF/ETZ & 2 & 5 \\
SSF/OOF & 1 & 2.5 \\
\hline Total & 40 & 100 \\
\hline
\end{tabular}

Vegetation types: $00 \mathrm{~F}=$ open ombrophilous forest; $\mathrm{DOF}=$ dense ombrophilous forest; $\mathrm{ETZ}=$ ecological tension zone, and SSF = seasonal semideciduous forest.

ombrophilous forest and seasonal semideciduous forest accounted for $77.5 \%$ of the total number of records (Table 2).

The ENM showed higher suitability for the species from the coastal region of north Paraíba to center-east Alagoas, spreading westward between the states of Pernambuco and Alagoas. There are also few isolated suitable areas further west in Paraíba and in the coastal regions of Sergipe and Rio Grande do Norte (Figs. 2a and 2b).

The average model was considered statistically significant ( $p<0.01$ ) and had a good performance identifying suitable areas for the species (AUC $=0.982 \pm 0.004$ SD). The maximum training sensitivity plus specificity logistic threshold was 0.1691 , and the training omission was 0.0133 .

The environmental variable that most contributed to the ENM was the precipitation of coldest quarter (bio 19), with $70.6 \%$ relative contribution, followed by declivity $(6.3 \%)$, mean temperature of wettest quarter (bio 8; 5.5\%), and precipitation of wettest quarter (bio 16; $4.6 \%)$. The ranges with better probability of presence of $L$. forbesi for these variables were respectively $>600 \mathrm{~mm}$ for bio 19 , between 2 and $20 \%$ of declivity, about $20^{\circ} \mathrm{C}$ for bio 8 and $>900 \mathrm{~mm}$ for bio 16 (Fig. 3).

The suitable area estimated for $L$. forbesi is $20,344 \mathrm{~km}^{2}$ (Fig. 2b). Within this suitable area, $3,118.59 \mathrm{~km}^{2}$ are classified as forest fragments, but only $1,636.89 \mathrm{~km}^{2}$ might be considered as occupancy area (suitable fragments larger than $1 \mathrm{~km}^{2}$ ) (Fig. 2c) and scarce $241 \mathrm{~km}^{2}$ are currently under legal protection.

\section{DISCUSSION}

Areas of high suitability for L. forbesi are located on humid costal region and in dry transition zone, locally known as agreste. This subregion of the Atlantic Forest has the highest density of threatened bird taxa in the Neotropics, with three recently extinct endemic species plus one extinct in the wild (Roda et al., 2011; Pereira et al., 2014). Our results show that there are some forest patches with environmental suitability in Sergipe, and Dénes et al. (2011) and Leite et al. (2017) suggested that individuals might wander southwards, reaching to northern Bahia state. An individual was recorded recently in Sergipe, at Serra da Itabaiana (Silva \& Lima, 2016), an area climatically suitable for the species according to our model. Another recent record in the south of Rio Grande do Norte (Gurgel, 2016) may be the result of the dispersion of some individuals to the north, because in this state there is almost no area with suitability for the species. In this case, these individuals must be monitored and the vagrancy of individuals searching for rarer suitable territories should be investigated.

According to our model, suitable areas for $L$. forbesi extend predominantly over seasonal and ombrophilous forests. These forests are wetter than other vegetation types in the region and are located mostly in Pernambuco and Alagoas (IBGE, 2004). These states harbor much of the ombrophilous and seasonal forests, and the rains are intense mainly from the central coast of Pernambuco to the north coast of Alagoas (see Moura et al., 2007) where L. forbesi finds favorable habitats, especially near streams or rivers in the forests (see Pereira et al., 2006), being similar with its congener Leptodon cayanensis (Thiollay, 1994; Ferguson-Lees \& Christie, 2001). This may explain why the rainfall is the main environmental feature contributing for our ENM.

The species area of occupancy is very small compared to its extension of occurrence, especially when considering only the fragments larger than $1 \mathrm{~km}^{2}$. Most of these forest patches do not provide undisturbed, stable habitat for $L$. forbesi populations, given that only $15 \%$ of these patches are legally protected areas. Even with some resilience, the records in small forest fragments and within cities may be masking the real situation of the species.

Most of the forest patches inhabited by L. forbesi are located in private properties embed in plantations of sugar cane (Bensusan, 2006; Uchôa-Neto \& Tabarelli, 2003). These forests, with variable sizes, are highly fragmented and certainly will not be converted into National Parks or other public protected areas. For these unique forest remnants and its endemic and threatened animals and plants we suggest public policies to promote the creation of private protected areas, known as Private Reserves of Natural Heritage (Reservas Particulares do Patrimônio Natural, RPPNs in Portuguese). RPPNs play an important role in the conservation of endemic and threatened birds in the Atlantic Forest (Oliveira et al., 2010), and the maintenance of the Pernambuco Center of Endemism biodiversity could be granted with the creation of RPPNs in forest fragments. Specifically in the case of $L$. forbesi, the importance of the connection of these fragments rest on the necessity of ecological corridors (Bennett, 2003), which would ensure gene flow and evolutionary processes' maintenance in a regional scale (Campanili \& Prochnow, 2006).

Forest patches with high suitability for the species such as Murici Ecological Station, Private Reserve of Frei Caneca, Santa Justina, Serra Grande and Trapiche Mills must be prioritized in conservation actions and efforts. 

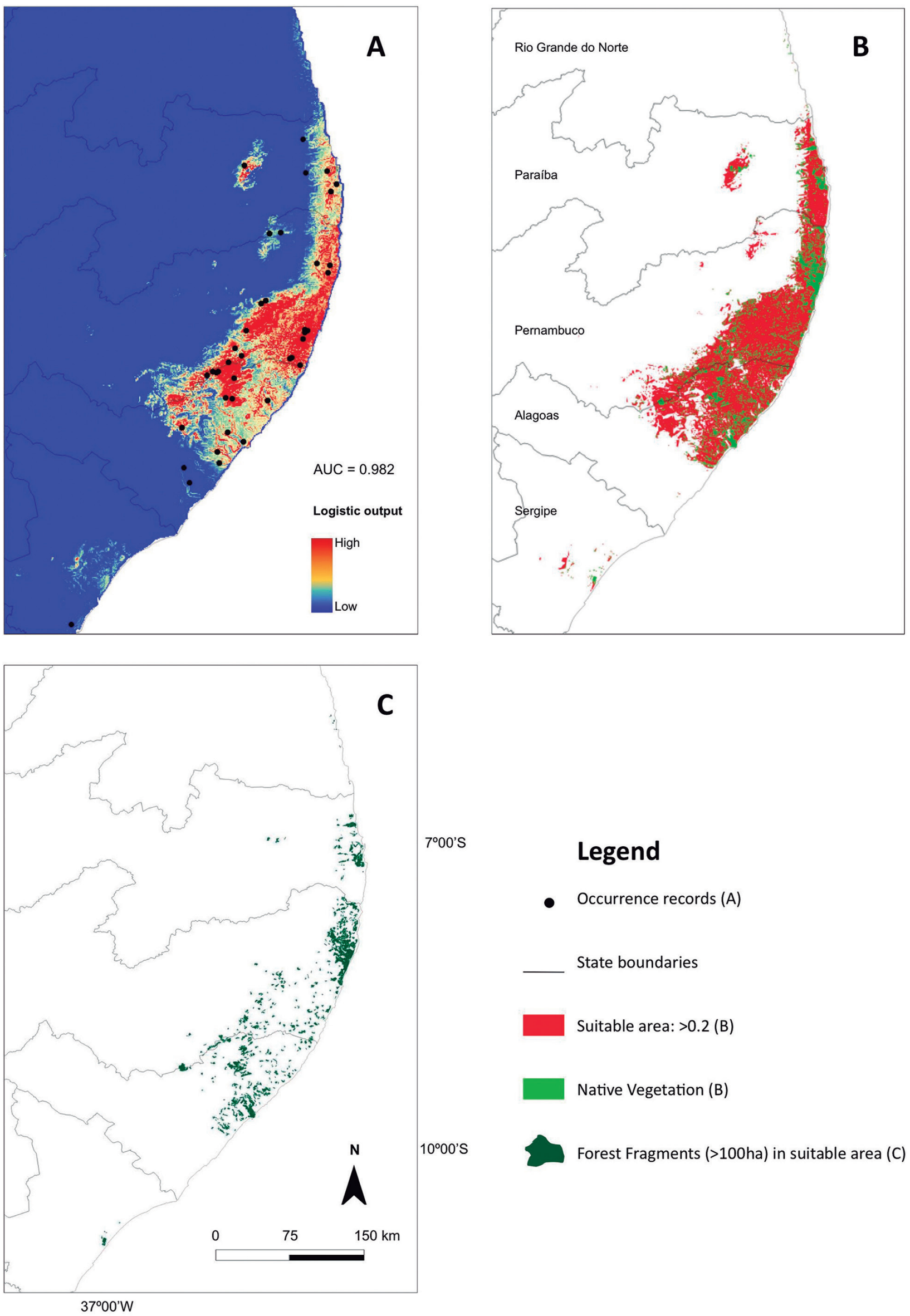

\section{Legend}

- Occurrence records $(\mathrm{A})$

State boundaries

Suitable area: $>0.2$ (B)

Native Vegetation (B)

Forest Fragments (>100ha) in suitable area (C)

Figure 2. (A) Potential distribution maps of Leptodon forbesi continuous model (probability of presence from 0 to 1: warmer colors show areas with better environmental conditions based on the species occurrence records (black points); (B) Binary model: suitable areas in red color (probability of presence $\geq 0.2$ ) and forest fragments in gray color (probability of presence $<0.35$ ); (C) Forest fragments $>100$ ha in suitable area, adopted here as distribution area of Leptodon forbesi. 

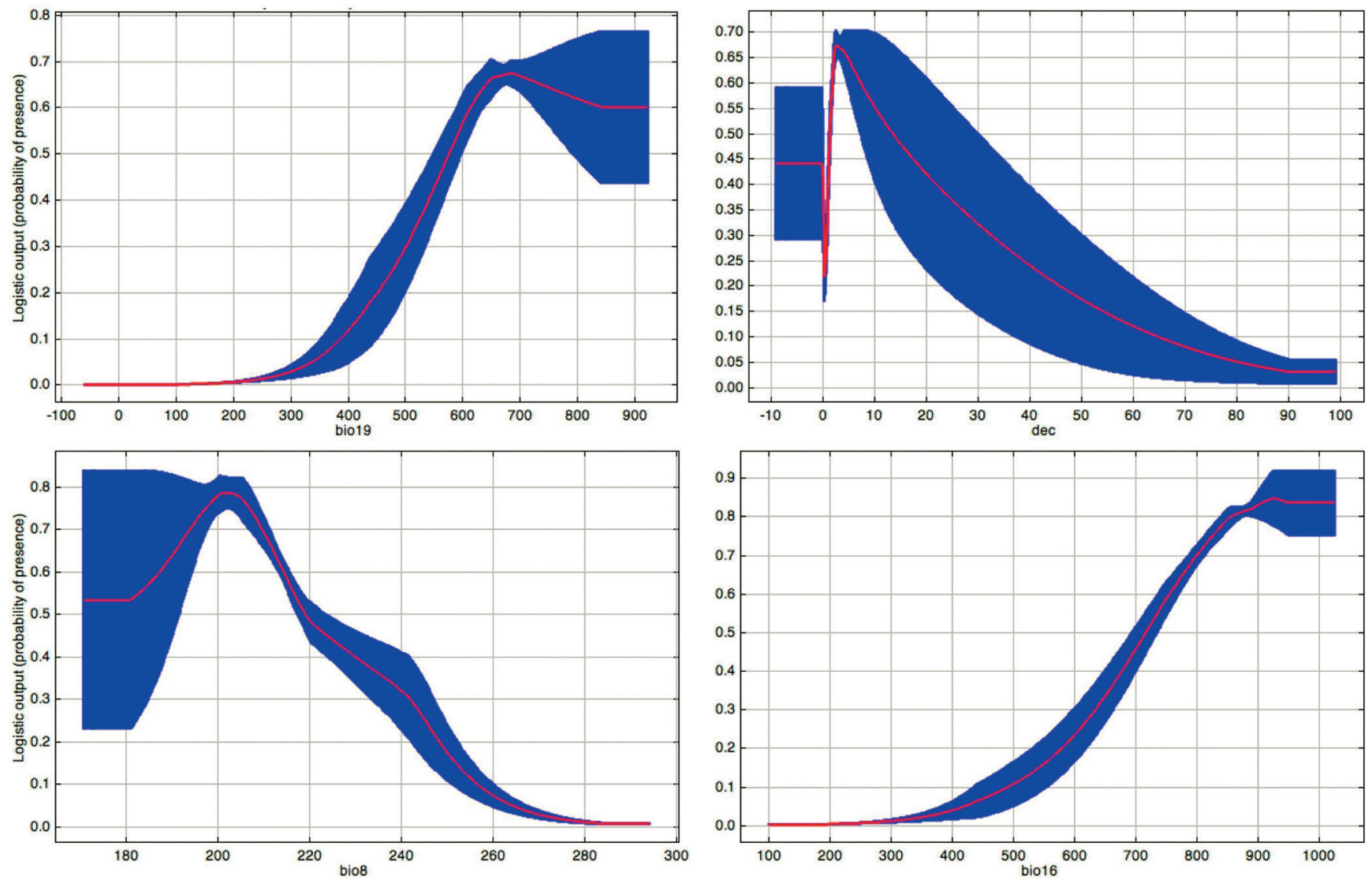

Figure 3. Response curves of the four predictors variables that most contributed to the model of Leptodon forbesi. Precipitation of coldest quarter (bio 19) (mm), declivity (dec) (\%), mean temperature of wettest quarter (bio 8) $\left({ }^{\circ} \mathrm{C} \times 10\right)$, and precipitation of wettest quarter (bio 16) (mm).

These proteced areas could serve as the core of an ecological corridor, as suggested by Tabarelli et al. (2006). Moreover, captive breeding is also recommended as a part of a strategy of ex-situ conservation, as individuals of the congener Leptodon cayanensis has been kept successfully in captivity in some Brazilian zoos, and the expertise can be used in benefit of the L. forbesi.

We call for conservation action plans, sounding the alarm for the necessity of innovative and dare measures to stop the ongoing extinction process faced in Pernambuco Center of Endemism (Teixeira, 1986; Coimbra-Filho \& Câmara, 1996; Pereira et al., 2014).

\section{ACKNOWLEDGEMENTS}

The first author would like to thank CAPES (Coordenação de Aperfeiçoamento de Nível Superior) for the PhD Scholarship and to the professors of the Postgraduate course in Ethnobiology and Conservation of Nature from UFRPE. Yuri Raia kindly provided the photograph of $L$. forbesi. We also thanks to José da Silva Nogueira Filho (Santa Justina), Fernando Pinto (IPMA) and Alberto Fonseca (MPE AL). LFS receives a grant from Conselho Nacional de Desenvolvimento Científico e Tecnológico (CNPQ), and funds for the studies in Pernambuco Center of Endemism are provided by the Fundação de Amparo à Pesquisa do Estado de São Paulo (FAPESP, \#2017/23548-2).

\section{REFERENCES}

Amaral, S.; Costa, C.B.; Arasato, L.S.; Ximenes, A.C. \& Rennó, C.D. 2013. AMBDATA: variáveis ambientais para modelos de distribuição de espécies (SDMs). In: Simpósio Brasileiro de Sensoriamento Remoto, 16º Anais. Foz do Iguaçu, Pr., INPE. p. 6930-6937. [DVD]. Available at: urlib. net/3ERPFQRTRW34M/3E7GH36. Access in: 19/06/2015.

Baldwin, R.A. 2009. Use of maximum entropy modeling in wildlife research. Entropy, 11(4): 854-866.

Bennett, A.F. 2003. Linkages in the Landscape: The Role of Corridors and Connectivity in Wildlife Conservation. Gland, Switzerland, IUCN.

Bensusan, N. 2006. Conservação da biodiversidade em áreas protegidas. Rio de Janeiro, Editora FGV.

Brasil. Ministério do Meio Ambiente (MMA). 2014. Portarias № 444 e № 445, de 18 de dezembro de 2014. Seção 1245. Brasilia, Diário Oficial da União. p. 121-130.

Brooks, T. \& Balmford, A. 1996. Atlantic forest extinctions. Nature, 380: 115.

Brooks, T.; Tobias, J. \& Balmford, A. 1999. Deforestation and bird extinction in the Atlantic forest. Animal Conservation, 2(3): 211-222.

Brown, J.L. 2014. SDMtoolbox: a python-based GIS toolkit for landscape genetic, biogeographic, and species distribution model analyses Methods in Ecology and Evolution, 5(4): 694700 Available at: https://www.jasonleebrown.org/ SDMtoolbox/current/User Guide SDMtoolbox.pdf. Access in:02/08/2015.

Campanili, M. \& Prochnow, M. 2006. Mata Atlântica: uma rede pela floresta. Brasília, RMA.

Coimbra-Filho, A.F. \& Câmara, I.G. 1996. Os limites originais do bioma Mata Atlântica na região Nordeste do Brasil. Rio de Janeiro, FBCN.

Collar, N.J.; Gonzaga, L.P.; Krabbe, N.; Madroño-Nieto, A.; Naranjo, L.G.; Parker, T.A. \& Wege, D.C. 2000. Aves Amenazadas de las Americas. Quito, BirdLife International. 
Del Hoyo, J.; Collar, N.J.; Christie, D.A.; Elliott, A. \& Fishpool, L.D.C. 2014. Illustrated Checklist of the Birds of the World. Vol. 1: Non Passerines. Barcelona/Cambridge, Lynx Edicions/BirdLife International.

Dénes, F.V.; Silveira, L.F.; Seipke, S.; Thorstrom, R.; Clarck, W.S. \& Thiollay, J. 2011. The White-collared Kite (Leptodon forbesi Swann, 1922) and a review of the taxonomy of the Grey-headed Kite (Leptodon cayanensis Lathan, 1790). Wilson Journal of Ornithology, 123(2): 323-331.

Dormann, C.F.; Mcpherson, J.M.; Araújo, M.B.; Bivand, R.; Bolliger, J.; Carl, G.; Davies, R.G.; Hirzel, A.; Jetz, W.; Kissling, W.D.; Kühn, l.; Ohlemüller, R.; Peres-Neto, P.R.; Reineking, B.; Schröder, B.; Schurr, F.M. \& Wilson, R. 2007. Methods to account for spatial autocorrelation in the analysis of species distributional data: a review. Ecography, 30(5): 609-628.

Elith, J. 2002. Quantitative methods for modeling species habitat: comparative performance and an application to Australian plants. In: Ferson, S. \& Burgman, M. Quantitative Methods for Conservation Biology. New York, Springer-Verlag. p. 39-58.

Ferguson-Lees, J. \& Christie, D.A. 2001. Raptors of the world. New York, Houghton Mifflin.

Fielding, A.H. \& Bell, J.F. 1997. A review of methods for the assessment of prediction errors in conservation presence/absence models. Environmental Conservation, 24(1): 38-49.

Fundação SOS Mata Atlântica. 2015. Atlas. Available at: http://mapas.sosma. org.br. Access in: 12/12/2015.

Giorgi, A.P.; Rovzar, C.; Davis, K.S.; Fuller, T.; Buermann, W.; Saatchi, S.; Smith, T.B.; Silveira, L.F. \& Gilleespie T.W. 2014. Spatial conservation planning framework for assessing conservation opportunities in the Atlantic Forest of Brazil. Applied Geography, 53: 369-376.

Gurgel, D.F. 2016. Leptodon forbesi (Swann, 1922). WA2263455, In:WikiAves A Enciclopédia das Aves do Brasil. Available at: www.wikiaves.com.br/22 $63455 \& p=1 \& \mathrm{t}=c \& c=2401404 \& s=10196$. Access in: 10/07/2016.

Hijmans, R.J.; Cameron, S.E.; Parra, J.L.; Jones, P.G. \& Jarvis, A. 2005. Very high resolution interpolated climate surfaces for global land areas. International Journal of Climatology, 25: 1965-1978.

Hijmans, R.J.; Phillips, S.; Leathwick, J. \& Elith, J. 2017 dismo: Species distribution modeling. $R$ package version 1.1-4. Available at: https:// cran.r-project.org/web/packages/dismo.

Instituto Brasileiro de Geografia e Estatística (IBGE). 1985. Atlas Nacional do Brasil, Região Nordeste. Rio de Janeiro, IBGE.

Instituto Brasileiro de Geografia e Estatística (IBGE). 2004. Mapa da vegetação do Brasil. Escala 1:5.000.00. 3. ed. Rio de Janeiro, Ministério do Planejamento e Orçamento e Gestão.

International Union for Conservation of Nature and Natural Resources (IUCN). 2001. IUCN Red List Categories and Criteria: Version 3.1. IUCN Species Survival Commission. IUCN, Gland, Switzerland and Cambridge, U.K.

International Union for Conservation of Nature and Natural Resources (IUCN). 2016. Leptodon forbesi - The IUCN Red List of Threatened Species. Cambridge, IUCN. Available at: http://doi.org/10.2305/IUCN.UK.2018-2. RLTS.T22724659A132176387.en. Access in: 16/10/2016.

International Union for Conservation of Nature and Natural Resources (IUCN). 2018. Leptodon forbesi. e.T22724659A132176387. Available at: http:// doi.org/10.2305/IUCN.UK.2018-2.RLTS.T22724659A132176387.en.

The IUCN Red List of Threatened Species 2018. Leptodon forbesi: e.T22724659A132176387. http://doi.org/10.2305/IUCN.UK.2018-2. RLTS.T22724659A132176387.en.

Jarvis, A.; Reuter, H.I.; Nelson, A. \& Guevara, E. 2008. Hole-filled SRTM for the globe. Version 4, 2008. Available at: www.cgiar-csi.org/data/srtm-90mdigital-elevation-database-v4-1. Access in: 10/03/2014.

Leite, G.A.; Santos, T.M.; Sampaio, S.; Filadelfo, T. \& Dénes, F.V. 2017. First documented recomended record of White-collared Kite Leptodon forbesi in Bahia state, Brazil. Cotinga, 39: 95-98.
Liu, C.; Pam, M.; Dawson, T.P. \& Pearson, R.G. 2005. Selecting thresholds of occurrence in the prediction of species distributions. Ecography, 28(3): 385-393.

Marco-Júnior, P. \& Siqueira, M.F. 2009. Como determinar a distribuição potencial de espécies sob uma abordagem conservacionista? Megadiversidade, 5(1-2): 65-76.

Moura, M.S.B.; Galvincio, J.D.; Brito, L.T.L.; Souza, L.S.B.; Sá, I.I.S. \& Silva, T.G.F. 2007. Clima e água de chuva no Semi-Árido. Available at: https://ainfo. cnptia.embrapa.br/digital/bitstream/CPATSA/36534/1/0PB1515.pdf. Access in: 01/02/2014.

Nimer, E. 1977. Clima. In: IBGE. Geografia do Brasil, Região Nordeste. Rio de Janeiro, IBGE. v. 2. p. 47-84.

Oliveira, V.B.; Paglia, A.P.; Fonseca, M. \& Guimarães, E. 2010. RPPN e biodiversidade: 0 papel das reservas particulares na proteçãa da biodiversidade da Mata Atlântica. Belo Horizonte, Conservação Internacional/Fundação SOS Mata Atlântica/The Nature Conservancy.

Pearson, R.G.; Raxworthy, C.J.; Nakamura, M. \& Peterson, A.T. 2007. Predicting species' distributions from small numbers of occurence records: a test case using cryptic geckos in Madagascar. Journal of Biogeography, 34(1): 102-117.

Pereira, G.A.; Dantas, S.M. \& Periquito, M.C. 2006. Possível registro de Leptodon forbesi no Estado de Pernambuco. Revista Brasileira de Ornitologia, 14(4): 441-444.

Pereira, G.A.; Dantas, S.M.; Silveira, L.F.; Roda, S.A.; Albano, C.; Sonntag, F.A.; Leal, S.; Periquito, M.C.; Malacco, G.B. \& Lees, A.C. 2014. Status of the globally threatened forest birds of northeast Brazil. Papéis Avulsos de Zoologia, 54(14): 177-194.

Phillips, S.J.; Anderson, R.P. \& Schapire, R.E. 2006. Maximum entropy modeling of species geographic distributions. Ecological Modelling, 190(3-4): 231-259.

Roda, S.A. \& Pereira, G.A. 2006. Distribuição recente e conservação das aves de rapina florestais do Centro Pernambuco. Revista Brasileira de Ornitologia, 14(4): 331-344

Roda, S.A.; Pereira, G.A. \& Albano, C. 2011. Conservação de aves endêmicas e ameaçadas do Centro de Endemismo Pernambuco. Recife, Editora Universitária da UFPE.

Seipke, S.H.; Dénes, F.V.; Pallinger, F.; Thorstrom, R.T.; Thiollay, J.M.; Silveira, L.F. \& Clarck, W.S. 2011. Field identification of White-collared Kite Leptodon forbesi and similar species in northeast Brazil. Neotropical Birding, 8: 29-39.

Silva, C. \& Lima, J.0. 2016. Primeiro registro documentado do gavião-depescoço-branco para o Parque Nacional Serra de Itabaiana, Sergipe, Brasil. Atualidades Ornitológicas, 193: 25.

Sistema Nacional de Unidades de Conservação (SNUC). 2004. Sistema Nacional de Unidades de conservação: texto da Lei 9.985 de 18 de julho de 2000 e vetos da presidência da República ao PL aprovado pelo congresso Nacional. 2. ed. São Paulo, Conselho Nacional da Reserva da Biosfera da Mata Atlântica.

Tabarelli, M. \& Santos, A.M.M. 2004. Uma breve descrição sobre a história natural dos brejos nordestinos. In: Pôrto, K.C.; Cabral, J.J.P. \& Tabarelli, M. (Orgs.). Brejos de altitude em Pernambuco e Paraíba. Brasília, Ministério do Meio Ambiente. p. 17-24.

Tabarelli, M.; Siqueira-Filho, J.A. \& Santos, A.M.M. 2006. Conservação da Floresta Atlântica ao norte do Rio São Francisco. In: Pôrto, K.C.; AlmeidaCortez, J.S. \& Tabarelli, M. (Orgs.). Diversidade biológica e conservação da Floresta Atlântica ao norte do Rio São Francisco. Brasilia, MMA. p. 41-48.

Teixeira, D.M. 1986. The avifauna of the northeastern Brazilian Atlantic forest: a case of mass extinction? Ibis, 128: 167-168.

Teixeira, D.M.; Nacinovic, J.B. \& Pontual, B. 1987. Notes on some birds of northeastern Brazil (2). Bulletin of the British Ornithologists' Club, 107(4): $151-157$. 
Thiollay, J.M. 1994. Family Accipitridae. In: Del Hoyo, J.; Elliott, A. \& Sargatal, J. Handbook of the Birds of the World. Barcelona, Lynx Edicions. v. 2, p. $52-205$

Thorn, J.S.; Nijman, V.; Smith, D. \& Nekaris, K.A.I. 2008. Ecological niche modeling as a technique for assessing threats and setting conservation priorities for Asian slow lorises (Primates: Nycticebus). Diversity and Distribution, 15(2): 289-298.

Trisurat, Y. \& Duengkae, P. 2011. Consequences of land use change on bird distribution at Sakaerat Environmental Research Station. Journal Ecology and Field Biology, 34(2): 203-214.
Uchôa-Neto, C.A.M. \& Tabareli, M. 2003. Diagnóstico e estratégia de conservação do Centro de Endemismo Pernambuco. Termo de Referência № CS FY02/00X Conservation International do Brasil. Centro de Pesquisas Ambientais do Nordeste, Recife. Available at: http://cepan.org.br/ uploads/file/arquivos/113b6d1f2de41e4699f56a94b2bf0a4b. Access in: 04/03/2014.

Wu, T.Y.; Lee, P.F.; Lin, R.S.; Wu, J.L. \& Walther, B.A. 2012. Modeling the distribution of rare or cryptic bird species of Taiwan. Taiwania, 57(4): 342-358. 